\title{
KUALITAS KARKAS AYAM PEDAGING YANG DIBERI RANSUM MENGANDUNG LIMBAH SAWI
}

\author{
Jola J.M.R. Londok*, John E.G. Rompis, dan Claudya Mangelep \\ Fakultas Peternakan Universitas Sam Ratulangi Manado, 95115
}

\begin{abstract}
ABSTRAK
Penelitian ini dilakukan untuk mengetahui pengaruh penggantian sebagian ransum dengan tepung limbah sawi terhadap kualitas karkas dan lemak abdomen ayam pedaging. Sebanyak 60 ekor ayam pedaging umur sehari unsex galur MB-202 $\mathrm{P}$, dibagi secara acak ke dalam 20 unit kandang masingmasing berisi tiga ekor. Ayam dipelihara selama 42 hari. Level penggantian ransum basal dengan perlakuan tepung limbah sawi yaitu: $0,5,10,15$, dan $20 \%$. Masing-masing perlakuan dengan 4 ulangan, sesuai dengan rancangan yang digunakan yaitu rancangan acak lengkap $5 \times 4$. Air minum dan pakan diberikan ad libitum. Sampai dengan umur 21 hari ayam diberi pakan pabrikan BR-21E untuk semua perlakuan, sedangkan perlakuan pakan diberikan pada hari ke-22 sampai akhir penelitian, lalu ayam dipotong. Data yang diperoleh dianalisis statistik dengan menggunakan uji $\mathrm{F}$ dan diuji lanjut Tukey (BNJ, beda nyata jujur) untuk perlakuan yang berbeda nyata. Hasil penelitian menunjukkan bahwa perlakuan kontrol memberi pengaruh yang berbeda nyata $(\mathrm{P}<0,05)$ dibanding empat perlakuan lainnya untuk bobot karkas, namun tidak berbeda nyata $(\mathrm{P}>0,05)$ untuk persentase karkas dan lemak abdomen. Dengan demikan maka limbah sawi putih dapat digunakan sebagai pengganti sebagian ransum sampai $20 \%$ bagi ayam pedaging dilihat dari persentase karkas dan persentase lemak abdomen.
\end{abstract}

Kata Kunci: Limbah sawi, ayam pedaging, kualitas karkas

*Korespondesi (corresponding author):

Email: jolalondok_unsrat@yahoo.com

\section{ABSTRACT}

CARCASS QUALITY OF
BROILERS FED RATION CONTAINING

WASTE OF SAWI. Study was conducted to evaluate the effect of substituting part of ration with sawi waste meal on carcass quality and abdominal fat of broilers. Total of sixty unsexed day old chick broilers of MB-202 P strain were randomly divided into twenty units of pens, each of pen was filled with three heads of chicks. Birds were maintained during forty days. Levels of substituting part of ration with sawi waste meal were $0,5,10,15$, and 20 percents. Each treatment had four replications using completely randomized design with $5 \times 4$. Fresh water and ration were given ad libitum. Birds from day old chick to the age of twenty one days old were fed with BR-21E ration for all treatments. The treatments of ration were fed at ages of twenty two days old to the end of study (period when all animals were slaughtered). Data were analyzed using $\mathrm{F}$ test and Tukey test for the significant $\mathrm{F}$ test. Results showed that control treatments were significantly different $(\mathrm{P}<0.05)$ with those others four treatments for carcass weight, but not significantly different with those others four treatments for carcass percentages and abdominal fat. Therefore, sawi waste meal can be used to substitute part of ration up to 20 percents for broilers ration in term of the carcass percentages and abdominal fat.

Key words: Sawi waste meal, broilers, carcass quality.

\section{PENDAHULUAN}

Limbah pasar di kota pada umumnya tergolong limbah organik sering 
menimbulkan permasalahan seperti timbulnya bau dari tumpukan limbah dan dapat menjadi sumber penyakit. Limbah yang banyak mengandung bahan organik tersebut berasal dari sayuran dan buahbuahan. Limbah sayuran adalah bagian dari sayuran, sayuran yang tidak dapat dijual atau dibuang. Salah satu di antara limbah sayuran adalah sawi putih. Potensi sawi putih sebagai bahan pakan alternatif untuk ayam pedaging dilihat dari kandungan zat-zat makanannya terutama protein sebesar 26\%. Kandungan energinya sebesar 3133 kkal/kg. Kadar airnya yang tinggi $(93,82 \%)$ menyebabkan secara fisik limbah sawi mudah busuk. Perlakuan kimiawi banyak dilakukan agar dapat menjamin ketersediaan limbah sawi sebagai pakan alternatif, namun pemberian secara langsung ataupun dikeringkan menjadi salah satu cara yang efektif. Untuk ayam pedaging, pemberian dengan cara dikeringkan lebih efektif karena akan dicampurkan ke dalam ransum dalam keadaan kering. Ketersediaan bahan pakan dalam suatu usaha peternakan hingga saat ini masih memegang peranan penting. Peningkatan produktivitas ayam pedaging ditunjang oleh kuantitas dan kualitas pakan yang dikonsumsi. Bahan pakan yang tepat, berimbang, mudah didapat, murah dan berkualitas serta tidak bersaing dengan kebutuhan manusia merupakan hal penting yang harus diperhatikan.
Ayam pedaging merupakan salah satu ternak alternatif untuk memenuhi permintaan masyarakat akan daging dan telah banyak diusahakan baik dalam skala kecil maupun besar. Ayam pedaging memiliki karakteristik dengan ciri khas pertumbuhan cepat, efesiensi dalam penggunaan ransum, masa panen pendek, menghasilkan daging berserat lunak, timbunan daging baik, serta kulit yang licin. Konsumen terutama negara-negara maju semakin meningkatkan kewaspadaannya terhadap bahan makanan asal produk hewani, Hal ini mengilhami para nutritionist untuk menyusun ransum yang memenuhi kebutuhan nutrisi (energi, asam amino, vitamin dan mineral) dan menghasilkan produk yang aman bagi konsumen (Daud, 2007). Pemberian pakan sumber serat dapat menjawab tantangan tersebut. Salah satu pakan sumber serat dan juga sumber protein adalah limbah sawi dengan kandungan nutrisi 23\% protein, $2.55 \%$ lemak, $16.74 \%$ serat kasar, $36.59 \%$ BETN, dan $21.1 \%$ abu, (Edeilweys, 2013). Kandungan $\mathrm{Ca}$ sebanyak $1.05 \%$, dan P sebanyak $0.37 \%$ (Direktorat Jenderal Hortikultura. 2012) dan energi $3133 \quad \mathrm{Kkal} / \mathrm{kg}$ (Nawangwulansari. 2012).

Pertumbuhan adalah korelasi peningkatan pada tubuh yang tampak pada interval waktu tertentu sesuai dengan karakteristik spesies, sehingga terdapat 
karakteristik kisaran tubuh untuk setiap spesies dan perkembangan serta ukuran tubuh dewasa. Bobot maksimum dan perkembangan dimunculkan oleh gabungan dari heriditas, nutrisi, dan manajemen yang merupakan faktor esensial yang mendukung laju tumbuh hewan. Penelitian penggunaan limbah sayuran dengan beberapa perlakuan yaitu pengukusan, perebusan dan penjemuran dapat dijadikan bahan pakan alternatif dalam penyusunan ransum unggas, khususnya ayam kampung super, yang diberikan $85 \%$ ransum basal ditambah $15 \%$ limbah sayur menunjukan performans yang optimal (Abun et al., 2007).

Karkas ayam pedaging menurut BSN (1995) ialah bagian dari ayam pedaging hidup, setelah dipotong, dibului, dikeluarkan organ dalam dan lemak abdominalnya, dipotong kepala dan leher serta kedua kakinya (ceker). Karkas unggas biasanya dijual kepada konsumen dalam bentuk karkas utuh, belahan karkas kiri dan kanan, seperempat karkas atau potongan-potongan karkas yang lebih kecil. Persentase karkas ayam broiler menurut Lesson and Summers (2008) adalah $73 \%$. Persentase pemotongan pada ayam broiler, ayam lokal dan kalkun meningkat selama pertumbuhan, peningkatan umur dan kenaikan bobot potong.Pada itik dan unggas yang lebih kecil misalnya burung puyuh, persentase pemotongan selama pertumbuhan secara relatif adalah konstan (Soeparno, 1994).

\section{MATERI DAN METODE PENELITIAN}

Penelitian ini dilaksanakan di kandang unggas Fakultas Peternakan Universitas Sam Ratulangi Manado. Digunakan 60 ekor ternak ayam pedaging

Tabel 1. Susunan Pakan Perlakuan dan Kandungan zat-zat Makanannya

\begin{tabular}{lcclcc}
\hline Susunan Pakan & $\mathrm{R}_{0}$ & $\mathrm{R}_{1}$ & $\mathrm{R}_{2}$ & $\mathrm{R}_{3}$ & $\mathrm{R}_{4}$ \\
\hline Ransum Basal (\%) & 100 & 95 & 90 & 85 & 80 \\
Limbah Sawi Putih (\%) & 0 & 5 & 10 & 15 & 20 \\
\hline Total & 100 & 100 & 100 & 100 & 100 \\
\hline Kandungan Zat-zat Makanan & & & & & \\
\hline Protein(\%) & 20,56 & 20,68 & 20,81 & 20,92 & 21,05 \\
Serat Kasar (\%) & 4,17 & 4,80 & 5,43 & 6,06 & 6,70 \\
Lemak (\%) & 6,84 & 6,64 & 6,44 & 6,24 & 6,04 \\
Ca (\%) & 1,03 & 1,03 & 1,03 & 1,03 & 1,03 \\
P(\%) & 0,83 & 0,81 & 0,79 & 0,76 & 0,74 \\
EM (Kkal/kg) & 3082,37 & 3084,90 & 3087,43 & 3090.0 & 3092,5 \\
\hline Keterangan: EM:
\end{tabular}

Keterangan: EM: energi metabolis, Ca: calcium, P: phosphor. 
galur MB-202 P umur sehari, yang diperoleh dari perusahan pembibitan ayam pedaging PT Japfa Comfeed Indonesia Tbk. Poultry Breeding Division Unit 13 Kauditan, Desa Tumaluntung Kec. Kauditan Kab. Minahasa Utara. Penelitian ini terdiri dari 20 Unit percobaan dan setiap unit ditempatkan masing-masing 3 ekor ayam. Penelitian ini menggunakan rancangan acak lengkap (RAL) dengan 5 perlakuan dan 4 ulangan dan dilanjutkan dengan uji Tukey apabila terdapat perbedaan di antara perlakuan. Pada Periode starter ayam diberi pakan pabrikan BR-21E dengan kandungan protein kasar 20-22\%. Setelah ayam berumur 21 hari diberi pakan perlakuan (Tabel 1). Bahan pakan penyusun ransum terdiri dari jagung kuning, bungkil kedele, bungkil kelapa, tepung ikan, dedak, dan limbah sawi putih.

Peubah yang diukur pada penelitian ini adalah: bobot karkas, persentase karkas, dan persentase lemak abdominal. Perhitungan untuk masing-masing peubah menurut Subekti et al. (2012) adalah sebagai berikut:

Bobot karkas $=$ bobot hidup - (bulu, kepala, kaki, jeroan, darah, leher)

$$
\begin{aligned}
& \text { Persentase karkas } \\
& =\frac{\text { berat karkas }}{\text { berat hidup }} \times 100 \%
\end{aligned}
$$

$$
\begin{aligned}
& \text { Persentase lemak abdomen } \\
& =\frac{\text { berat lemak abdomen }}{\text { berat hidup }} \times 100 \%
\end{aligned}
$$

Metode Pemotongan. Untuk memperoleh hasil pemotongan yang baik, ayam yang akan dipotong dipuasakan terlebih dahulu agar saluran pencernaan bersih sehingga mempermudah penanganan dan pengamatan. Cara pemotongan yang dilakukan dalam penelitian ini adalah dengan metode Kosher, yaitu memotong arteri karotis, vena jugularis dan oesofagus. Pada saat penyembelihan, darah harus keluar sebanyak mungkin. Jika darah dapat keluar secara sempurna, maka beratnya sekitar $4 \%$ dari bobot tubuh. Setelah proses penyembelihan, dilakukan pencabutan dan pembersihan bulu. Proses pembersihan bulu ini dapat dipermudah dengan sebelumnya mencelupkan ayam ke dalam air panas dengan suhu $50-54^{\circ} \mathrm{C}$ selama 30 detik. Proses selanjutnya adalah pemotongan bagian kepala dan kaki serta pengeluaran organ dalam. Proses pengeluaran organ dalam dimulai dari pemisahan tembolok dan trakhea serta kelenjar minyak bagian ekor. Kemudian pembukaan rongga badan dengan membuat irisan dari kloaka ke arah tulang dada. Kloaka dan organ dalam lalu dikeluarkan, kemudian dilakukan pemisahan tiap-tiap organ (Soeparno, 1994). 


\section{HASIL DAN PEMBAHASAN}

Pengaruh penggantian ransum dengan tepung limbah sawi sampai $20 \%$ terhadap kualitas karkas ayam pedaging disajikan dalam Tabel 2.

\section{Pengaruh Perlakuan terhadap bobot karkas ayam pedaging}

Rataan bobot karkas ayam pedaging dari penelitian pada minggu ke 6 dengan penggantian sebagian ransum dengan tepung limbah sawi menghasilkan bobot karkas antara 1441,50 sampai 1682,00 g/ekor (Tabel 2). Hasil analisis keragaman menunjukkan bahwa perlakuan memberikan pengaruh nyata $(\mathrm{P}<0,05)$ terhadap bobot karkas ayam broiler. Berdasarkan uji lanjut diketahui bahwa $\mathrm{R}_{0}$ berbeda nyata dengan perlakuan $\mathrm{R}_{1}, \mathrm{R}_{2}$, $\mathrm{R}_{3}$, $\mathbf{R}_{4}$. Namun antar perlakuan yang menggunakan sawi berbeda tidak nyata ( $\mathrm{P}>0,05)$. Perlakuan $\mathrm{R}_{0}$ menghasilkan bobot karkas yang paling tinggi. Produksi karkas erat hubungannya dengan bobot hidup yaitu peningkatan bobot hidup diikuti oleh peningkatan bobot karkas. Nilai persentase karkas diperoleh dengan membandingkan bobot karkas dengan bobot hidup. Tabel 2 menunjukkan bobot karkas tertinggi terlihat pada perlakuan $\mathrm{R}_{0}$ (ransum basal) yaitu 1682,00. Hal ini mengindikasikan bahwa penggantian sebagian ransum dengan tepung limbah sawi belum mampu memberikan bobot karkas yang sama dibanding ayam pedaging yang menerima ransum basal.

\section{Pengaruh Perlakuan terhadap persentase karkas ayam pedaging}

Rataan persentase karkas ayam pedaging dari penelitian pada minggu ke 6 dengan penggantian sebagian ransum dengan tepung limbah sawi menghasilkan persentase karkas antara 69,99 sampai 77,79\% (Tabel 2). Persentase karkas ayam pedaging yang menerima ransum control dan perlakuan limbah sawi putih sampai 15\% masih sesuai dengan Lesson dan Summers (2008) yaitu sebesar $73 \%$. Terdapat kecenderungan menurun seiring dengan peningkatan level limbah sawi putih, namun belum menunjukkan perbedaan yang nyata. Hasil analisis keragaman menunjukkan bahwa perlakuan memberikan pengaruh yang tidak nyata $(\mathrm{P}>0,05)$ terhadap persentase karkas ayam broiler. Persentase karkas erat hubungannya dengan bobot hidup yang diikuti oleh bobot karkas (Yuanita et al., 2009). Persentase karkas selain disebabkan oleh bobot hidup yang dihasilkan, dipengaruhi pula oleh penanganan dalam 
Tabel 2. Rataan pengukuran peubah kualitas karkas ayam pedaging

\begin{tabular}{lccccc}
\hline \multirow{2}{*}{ Peubah } & \multicolumn{5}{c}{ Perlakuan } \\
\cline { 2 - 6 } \multicolumn{1}{c}{} & $\mathrm{R}_{0}$ & $\mathrm{R}_{1}$ & $\mathrm{R}_{2}$ & $\mathrm{R}_{3}$ & $\mathrm{R}_{4}$ \\
\hline Bobot Karkas & $1682,00^{\mathrm{a}}$ & $1526,5^{\mathrm{b}}$ & $1524,25^{\mathrm{b}}$ & $1502,25^{\mathrm{b}}$ & $1441,50^{\mathrm{b}}$ \\
Persentase karkas & 77,793 & 73,289 & 73,847 & 73,067 & 69,995 \\
Persentase lemak abdomen & 1,783 & 1,644 & 1,567 & 1,498 & 1,289 \\
\hline
\end{tabular}

Keterangan: superskrip berbeda pada baris yang sama menunjukkan perbedaan nyata $(\mathrm{P}<.05)$

proses pemotongan. Strain ayam juga dapat mempengaruhi persentase karkas (Risnajati, 2012). Selain itu faktor lingkungan juga mempengaruhi laju pertumbuhan dan komposisi bobot karkas dan persentase karkas yang biasanya meningkat seiring dengan meningkatnya bobot hidup ayam (Soeparno, 1994).

\section{Pengaruh Perlakuan terhadap persentase lemak abdomen ayam pedaging}

Persentase lemak abdomen dari ayam pedaging yang diberi ransum menggunakan limbah sawi putih dapat dilihat pada Tabel 2. Dengan kisaran antara 1,29 sampai dengan $1,79 \%$, dapat dilihat dalam Tabel 2. Hasil ini di bawah rata-rata lemak abdomen ayam pedaging yang dipelihara 6 minggu yang berkisar anatara $2.49-2.50 \%$ dari bobot badan ayam pedaging (Pratikno, 2011). Analisis keragaman menunjukkan bahwa perlakuan memberikan pengaruh yang tidak nyata $(\mathrm{P}>0.05)$ terhadap persentase lemak abdomen. Kubena et al. (1974) menyatakan bahwa penimbunan lemak tubuh (lemak abdomen) dipengaruhi oleh beberapa faktor, yaitu temperatur, kandang atau ruang kandang, kadar energi ransum, umur, dan jenis kelamin. Imbangan energi metabolisme dan protein yang digunakan dalam penelitian ini yaitu 3163,59-3041,84 $\mathrm{kkal} / \mathrm{kg}$ dan protein 21,05-20,16\% juga hampir sama dengan standar kebutuhan yang direkomendasikan oleh Lesson dan Summers (2008), bahwa imbangan energi metabolisme dan protein ransum ayam broiler sesuai fase umur yang digunakan dalam penelitian ini yaitu sebesar 3100 $\mathrm{kkal} / \mathrm{kg}$ dan protein adalah $20 \%$. Imbangan energi dan proteinnya sama sehingga walaupun semakin tinggi penggunaan limbah sawi putih sebagai pengganti sebagian ransum basal persentase lemak abdomennya tidak berbeda.

\section{KESIMPULAN}

Limbah sawi putih dapat digunakan sebagai pengganti sebagian ransum sampai $20 \%$ bagi ayam pedaging dilihat dari 
persentase karkas dan persentase lemak abdomen.

\section{DAFTAR PUSTAKA}

Abun., D. Rusmana, D. Saefulhadjar. 2007. Efek pengolahan limbah sayuran secara mekanis terhadap nilai kecernaan pada ayam kampung super jj-101. Jurnal Ilmu Ternak. $7(2): 81-86$.

Daud M., W.G. Piliang, I Putu Kompiang. 2007. Persentase dan kualitas karkas ayam pedaging yang diberi probiotik dan Prebiotik dalam ransum. JITV 12(3): 167-174.

Direktorat Jenderal Hortikultura dan Badan Pusat Statistik. 2012. Pedoman Teknis Pelaksanaan Pengembangan Hortikultura Tahun 2012. Kementerian Pertanian, Direktorat Jenderal Hortikultura. Jakarta.

Edeilweys, N. 2013. Karakteristik Kimiawi Susu Sapi Perah Friesian Holstein (Fh) Yang Diberikan Pakan Komplit Berbasis Limbah Bahan Baku Lokal Berupa Limbah Sayur. Skripsi. Fakultas Peternakan Universitas Hasanudin Makassar.

Kubena, L.F., J.W. Deaton, T.C. Chen, F.N. Reece. 1974. Factors influencing the quantity of abdominal fat in broilers 1. Rearing temperature, sex age or weight, and dietary choline chloride and inositol supplementation. Poultry Sci. 53: 211-241.

Lesson, S. dan J.D. Summers. 2008. Commercial Poultry Nutrition. $3^{\text {rd }}$ ed. Nottingham (UK): Nottingham University Pr.
Nawangwulansari，D. 2012. Penggunaan limbah organik pasar sebagai pengganti dedak hingga $30 \%$ pada ransum ternak itik petelur. Skripsi. Fakultas Peternakan Universitas Diponegoro Semarang.

Pratikno H. 2011. Lemak abdominal daging broiler (Gallus sp.) karena pengaruh ekstrak kunyit (curcuma domestica). J. Bioma 13(1):17-24.

Risnajati, D. 2012. Perbandingan bobot akhir, bobot karkas dan pesentase karkas berbagai strain broiler. Sains Peternakan 10(1):11-14.

Soeparno. 1994. Ilmu dan Teknologi Daging. Cetakan kedua. Yogyakarta (ID): Gadjah Mada University Press.

Steel, R.G.D dan J.H. Torrie. 2002. Prinsip dan Prosedur Statistika. Suatu Pendekatan Biometrik. Ed ke-10. Terjemahan dari Principles and Procedures of Statistics, penerjemah B. Sumantri. PT Gramedia. Jakarta.

Subekti, K., H. Abbas, K.A. Zura. 2012. Kualitas karkas (berat karkas, persentase karkas dan lemak abdomen) ayam broiler yang diberi kombinasi CPO (crude palm oil) dan vitamin C (Ascorbic Acid) dalam ransum sebagai anti stress. Jurnal Peternakan Indonesia 14(3):447-453.

Yuanita, I., S. Murtini, Imam Rahayu HS. 2009. Performans dan kualitas ayam pedaging yang diberi pakan tambahan ampas buah merah (Pandanus conoideus). Seminar Nasional Teknologi Peternakan Veteriner 586-593. http://peternakan.litbang.pertanian.g o.id/fullteks/semnas/pro09-86.pdf (Diunduh pada 24 Juli 2016). 